\title{
Evaluating the factors influencing perinatal outcome in breech presentation
}

\author{
Dharmendra Raut, Srividya Tadru*, Bhupendra Patil, Prachi Koranne
}

\begin{abstract}
Department of Obstetrics and Gynecology, Government Medical College, Akola, Maharashtra University of Health
\end{abstract} Sciences, Akola, Maharashtra, India

Received: 28 May 2020

Accepted: 03 July 2020

\author{
*Correspondence: \\ Dr. Srividya Tadru, \\ E-mail: srividyatadru@gmail.com
}

Copyright: (c) the author(s), publisher and licensee Medip Academy. This is an open-access article distributed under the terms of the Creative Commons Attribution Non-Commercial License, which permits unrestricted non-commercial use, distribution, and reproduction in any medium, provided the original work is properly cited.

\section{ABSTRACT}

Background: The objective of this study was to analyse the current obstetric practice regarding breech presentation, document the incidence, perinatal outcome and the factors influencing perinatal outcome in breech deliveries.

Methods: It was a retrospective observational study including 252 cases of breech presentation during January 2018 to December 2019 in a tertiary teaching institute in Vidarbha region of Maharashtra.

Results: Total number of breech deliveries 252 (incidence is 2.5\%). Caesarean section for breech presentation 95 (37.6\%). With vaginal deliveries the Apgar score at 5 min below 7 were among 48 out of 157 breech deliveries whereas with LSCS it was only amongst 7 out of 95 deliveries. The maximum percentage of perinatal mortality is seen with birth weight below 2000 gm. Maximum mortality is seen prior to 32 weeks and in babies who delivered by vaginal route. Respiratory distress with prematurity and severe birth asphyxia are the common causes of perinatal deaths. Total $32(12.69 \%)$ babies were transferred to NICU. $20.38 \%$ of the total vaginal breech deliveries and $5.26 \%$ of the total LSCS were transferred to NICU. Out of total 32 NICU admissions 22 are for the preterm babies and babies with birth weight below $2000 \mathrm{gm}$.

Conclusions: The perinatal outcome does not depend only on the mode of delivery, it is also affected by the weight of the baby, its maturity, associated congenital anomalies, equipped neonatal intensive care unit and also substantially on the expertise of the obstetrician and the neonatologist.

Keywords: Apgar score, Breech, Birth weight, Mode of delivery, Perinatal outcome, Preterm

\section{INTRODUCTION}

About $3-4 \%$ of all pregnancies reach term with a fetus in the breech presentation. ${ }^{1}$ Fetal abnormality, prematurity, abnormal amniotic fluid volumes and low-lying placenta are all the risk factors for breech presentation.

The major contributing factors in relation to perinatal mortality was prematurity and low birth weight.

The percentage of breech deliveries decreases with advancing gestational age from $22-25 \%$ of births prior to 28 weeks' gestation to $7-15 \%$ of births at 32 weeks' gestation to $3-4 \%$ of births at term. ${ }^{1}$
Controversy exists among clinicians regarding the mode of delivery for babies in a breech presentation at term with vaginal breech delivery becoming less common following the publication of the Term Breech trial in $2000 .^{2}$

In spite of various improvements in methods of diagnosis, antenatal care, newer and safer anaesthetic agents and techniques of delivery, breech presentation is always at a greater risk than cephalic presentation with respect to perinatal morbidity and mortality.

In primigravida this problem is compounded by the fact that the foetus is traversing through an untested pelvis. 
ACOG recommendations beyond 2006 have indicated that the decision regarding the mode of delivery should consider patients' wishes and the experience of the provider, because some follow-up studies revealed no differences in maternal or neonatal outcomes between planned caesarean and vaginal delivery groups. ${ }^{3-6}$ It is necessary to give the parents not only a live baby but also a child both physically and mentally healthy.

With astonishing growth of medicolegal responsibilities, the breech presentation always puts the obstetrician in dilemma regarding the decision between vaginal delivery and caesarean section. Furthermore, with increasing awareness, smaller family norms, obstetricians favour an abdominal delivery in a breech presentation the intention being primarily to reduce the perinatal morbidity and mortality. Perinatal outcome in breech delivery is affected by other factors also like prematurity, low birth weight, congenital anomalies. Taking all these factors into consideration a retrospective study of the current obstetric practice regarding breech presentation and the other factors affecting the perinatal outcome in breech deliveries presenting at the time of labour was carried out.

\section{METHODS}

It was a retrospective observational study. The study includes 252 cases of breech presentation during January 2018 to December 2019 in a tertiary teaching institute in Vidarbha region of Maharashtra.

- Patients who underwent breech delivery either vaginal or cesarean section during the period January 2018 to December 2019 were included in the study.

- The data was collected in pre-designed proforma.

- A detailed medical and obstetric history was elicited.

- General examination was done and pelvis was assessed.

- USG to rule out congenital anomalies was done if possible.

- Correlation of foetal outcome to the mode of delivery, and to the length of $2^{\text {nd }}$ stage of labour was made.

- Most of the fetuses were allowed to deliver spontaneously up to the umbilical cord and then assistance was given to deliver arms and head. After coming head was delivered by suprapubic pressure and or Mauriceau Smellie Veit man oeuvre. Occasionally forceps were used for aftercoming head of breech.

- All the data regarding APGAR score at 1 and 5 mins, fetal injuries during birth and congenital malformation were recorded and documentation was done.

\section{Inclusion criteria}

- All registered and unregistered patients who underwent breech delivery either vaginal or caesarean section during the period January 2018 to December 2019 have been included.

\section{Exclusion criteria}

- Cases with macerated still birth and absent foetal heart sounds on admission have been excluded.

\section{Management of delivery}

- To allow spontaneous labour to start and vaginal delivery to occur.

- Elective Caesarean Section

\section{Types of vaginal delivery}

\section{Spontaneous breech delivery}

The baby is expelled entirely spontaneously without any traction or manipulation other than support to the baby. This form of delivery is rare in term fetus.

\section{Assisted breech delivery}

The infant is spontaneously delivered as far as the umbilicus but remainder of the body is delivered by assistance given by obstetrician.

\section{Total breech extraction}

The entire body of the baby is extracted by the obstetrician.

\section{Indications for caesarean section in breech presentation}

- Large baby

a. EBW $>3.8 \mathrm{~kg}$ by clinical examinations and USG

b. BPD >9.5 by USG.

- Footling breech

- Preterm breech

- Hyperextended head

- Placenta previa

- Contracted borderline or abnormal pelvis

- Chronic fetal distress, IUGR

- Cord prolapses

- Gravidas with poor obstetric history e.g. a difficult delivery or damaged baby.

- Elderly primi, H/o infertility or request for caesarean delivery.

\section{RESULTS}

Total number of deliveries in the study year January 2018 to December 2019: 9938. Total number of breech deliveries 252 incidence is $2.5 \%$.

Incidence of caesarean section in breech presentation 95 $(37.6 \%)$. 
Table 1: Mode of delivery versus Apgar score.

\begin{tabular}{|lll|}
\hline $\begin{array}{l}\text { Apgar score at 5 } \\
\text { min }\end{array}$ & $\begin{array}{l}\text { Vaginal } \\
\text { delivery }\end{array}$ & LSCS \\
\hline $7-10$ & $109(69.4 \%)$ & $88(92.6 \%)$ \\
\hline $4-6$ & $25(15.9 \%)$ & $5(5.2 \%)$ \\
\hline $1-3$ & $23(14.6 \%)$ & $2(2.1 \%)$ \\
\hline Total & $157(100 \%)$ & $95(100 \%)$ \\
\hline
\end{tabular}

With vaginal deliveries the Apgar score at 5 min below 7 were among 48 breech deliveries whereas with LSCS it was only amongst 7 deliveries. Perinatal mortality was marginally higher in the multiparous patients most of them delivered vaginally.
Table 4 shows the association of birth weight with the perinatal outcome. The maximum percentage of perinatal mortality is seen with birth weight below $2000 \mathrm{gm}$.

Maximum neonatal deaths occurred in babies below 2000 gm who underwent vaginal breech delivery.

Table 2: Parity versus perinatal mortality.

\begin{tabular}{|llll|}
\hline Parity & $\begin{array}{l}\text { Total number } \\
\text { of patients }\end{array}$ & $\begin{array}{l}\text { Perinatal } \\
\text { death }\end{array}$ & $\%$ mortality \\
\hline Primi & 94 & 12 & $12.76 \%$ \\
\hline Multi & 158 & 25 & $15.82 \%$ \\
\hline Total & 252 & 37 & $14.68 \%$ \\
\hline
\end{tabular}

Table 3: Birth weight versus perinatal mortality.

\begin{tabular}{|llllll|}
\hline Birth weight (grams) & Fresh still birth & Neonatal death & Total $(\%)$ & $\begin{array}{l}\text { No. of breech } \\
\text { deliveries }\end{array}$ & $\begin{array}{l}\text { \% of breech } \\
\text { deliveries }\end{array}$ \\
\hline$<1000$ & 2 & 3 & $5(14.2 \%)$ & 5 & $100 \%$ \\
\hline $1000-1500$ & 6 & 9 & $15(37.1 \%)$ & 28 & $53.57 \%$ \\
\hline $1500-2000$ & 2 & 6 & $8(22.8 \%)$ & 30 & $26.66 \%$ \\
\hline $2000-2500$ & 1 & 3 & $4(11.4 \%)$ & 75 & $5.33 \%$ \\
\hline $2500-3000$ & 1 & 2 & $3(8.5 \%)$ & 106 & $2.83 \%$ \\
\hline $3000-3500$ & 0 & 2 & $2(5.7 \%)$ & 8 & $25 \%$ \\
\hline Total & 12 & 25 & $37(100 \%)$ & 252 & $14.68 \%$ \\
\hline
\end{tabular}

Table 4: Neonatal death versus route of delivery.

\begin{tabular}{|llllll|}
\hline $\begin{array}{l}\text { Birth weight } \\
\text { (grams) }\end{array}$ & $\begin{array}{l}\text { Total number } \\
\text { of cases }\end{array}$ & $\begin{array}{l}\text { Total no. } \\
\text { of LSCS }\end{array}$ & $\begin{array}{l}\text { Neonatal } \\
\text { deaths in LSCS }\end{array}$ & $\begin{array}{l}\text { Total no. of vaginal } \\
\text { deliveries }\end{array}$ & $\begin{array}{l}\text { Neonatal deaths in } \\
\text { vaginal deliveries }\end{array}$ \\
\hline$<1000$ & 5 & 0 & $0(0 \%)$ & 5 & $3(12 \%)$ \\
\hline $1000-1500$ & 28 & 1 & $0(0 \%)$ & 27 & $7(28 \%)$ \\
\hline $1500-2000$ & 30 & 12 & $2(8 \%)$ & 18 & $6(24 \%)$ \\
\hline $2000-2500$ & 75 & 28 & $1(4 \%)$ & 47 & $2(8 \%)$ \\
\hline $2500-3000$ & 106 & 48 & $0(0 \%)$ & 58 & $2(8 \%)$ \\
\hline $3000-3500$ & 8 & 6 & $0(0 \%)$ & 2 & $2(8 \%)$ \\
\hline Total & 252 & 95 & $3(12 \%)$ & 157 & $22(88 \%)$ \\
\hline
\end{tabular}

Table 5: Perinatal mortality versus period of gestation.

\begin{tabular}{|lllll|}
\hline Period of gestation & No. of cases & Fresh still birth & Neonatal death & Total (fresh still birth + neonatal death) \\
\hline$<28$ weeks & 5 & 2 & 3 & $5(100 \%)$ \\
\hline $28-32$ weeks & 35 & 7 & 11 & $18(51.42 \%)$ \\
\hline $32-36$ weeks & 102 & 2 & 9 & $11(10.78 \%)$ \\
\hline $36-40$ weeks & 98 & 1 & 2 & $3(03.06 \%)$ \\
\hline$>40$ weeks & 12 & 0 & 0 & $0(0 \%)$ \\
\hline Total & 252 & 12 & 25 & $37(14.68 \%)$ \\
\hline
\end{tabular}

Maximum mortality is seen prior to 32 weeks and in babies who delivered by vaginal route. Though preterm breech is an indicator for caesarean section, 32 were delivered vaginally in study institute taking into account poor salvageability of $<1500 \mathrm{gm}$ in study neonatal intensive care unit. Respiratory distress with prematurity and severe birth asphyxia are the common causes of perinatal deaths. Congenital anomalies were detected in 5 $(1.98 \%)$ of this study cases. So, an ultrasound obstetrics is mandatory prior to caesarean section to rule out congenital anomalies. In this study $75 \%$ of patients were scanned. 
Table 6: Etiology of perinatal deaths.

\begin{tabular}{|lll|}
\hline Etiology & No. of deaths & Incidence \\
\hline Respiratory distress with prematurity & 11 & $44 \%$ \\
\hline Severe birth asphyxia & 6 & $24 \%$ \\
\hline Meconium aspiration syndrome & 4 & $16 \%$ \\
\hline Sepsis & 3 & $12 \%$ \\
\hline Intraventricular haemorrhage & 1 & $4 \%$ \\
\hline Total & 25 & $100 \%$ \\
\hline
\end{tabular}

Table 7: Congenital anomalies in breech babies.

\begin{tabular}{|lll|}
\hline $\begin{array}{l}\text { Congenital } \\
\text { anomalies }\end{array}$ & $\begin{array}{l}\text { Number of } \\
\text { babies }\end{array}$ & $\begin{array}{l}\text { Percentage of } \\
\text { total (252) }\end{array}$ \\
\hline Anencephaly & 2 & $0.79 \%$ \\
\hline Hydrocephalus & 1 & $0.39 \%$ \\
\hline Cleft lip & 1 & $0.39 \%$ \\
\hline Spina bifida & 1 & $0.39 \%$ \\
\hline Total & 5 & $1.98 \%$ \\
\hline
\end{tabular}

Both the cases of brachial plexus injury occurred in case of vaginal breech delivery and they recovered completely. Intraventricular hemorrhage occurred in one baby with birth weight $>3000$ gm during vaginal delivery who had difficulty in delivery of aftercoming head, this baby did not survive the perinatal period.
Total $32(12.69 \%)$ babies were transferred to NICU. $20.38 \%$ of the total vaginal breech deliveries and $5.26 \%$ of the total LSCS were transferred to NICU. Out of total 32 NICU admissions 22 are for the preterm babies and babies with birth weight below $2000 \mathrm{gm}$.

\section{Table 8: Birth injuries.}

\begin{tabular}{|ll|}
\hline Birth injuries & Number of babies \\
\hline Brachial plexus injuries & 2 \\
\hline Fracture femur & 1 \\
\hline Intraventricular hemorrhage & 1 \\
\hline Fracture clavicle & 0 \\
\hline ERBS palsy & 0 \\
\hline Total & 4 \\
\hline
\end{tabular}

Table 9: Weight of baby versus fetal morbidity in terms of transfer to neonatal intensive care unit (NICU).

\begin{tabular}{|llllll|}
\hline Weight $(\mathrm{gm})$ & $\begin{array}{l}\text { Total no. } \\
\text { of LSCS }\end{array}$ & $\begin{array}{l}\text { NICU transfer } \\
\text { amongst LSCS }\end{array}$ & $\begin{array}{l}\text { Total no. of } \\
\text { vaginal deliveries }\end{array}$ & $\begin{array}{l}\text { NICU transfer amongst } \\
\text { vaginal deliveries }\end{array}$ & $\begin{array}{l}\text { \% total breech } \\
\text { deliveries }\end{array}$ \\
\hline$<1000$ & 0 & 0 & 5 & 3 & $3(1.19 \%)$ \\
\hline $1000-1500$ & 1 & 1 & 27 & 10 & $11(4.36 \%)$ \\
\hline $1500-2000$ & 12 & 2 & 18 & 6 & $8(3.17 \%)$ \\
\hline $2000-2500$ & 28 & 2 & 47 & 3 & $5(1.98 \%)$ \\
\hline $2500-3000$ & 48 & 0 & 58 & 3 & $3(1.19 \%)$ \\
\hline $3000-3500$ & 6 & 0 & 2 & 2 & $2(0.79 \%)$ \\
\hline Total & 95 & $5(5.26 \%)$ & 157 & $27(20.38 \%)$ & $32(12.69 \%)$ \\
\hline
\end{tabular}

\section{DISCUSSION}

With vaginal deliveries the Apgar scores were poor. $30.5 \%$ of the vaginal breech deliveries had Apgar score less than 7 whereas it was only $7.3 \%$ with caesarean section (Table 1). Most of them occurred with low birth weight $<1500 \mathrm{gm}$ or with weight $>3500 \mathrm{gm}$. Short term neonatal outcome definitely seems better in the LSCS babies even with low birth weight or high birth weight. In a study, of the live births among the vaginal breech deliveries, 51.2\% had 1-minute Apgar score of $<7 .^{7}$ Perinatal mortality was marginally higher in the multiparous patients as most of them delivered vaginally (Table 2).
All fresh still births occurred during vaginal delivery and the causes being entrapment of the head, severe birth asphyxia and intraventricular haemorrhage (Table 8). Congenital anomalies were detected in $5(1.98 \%)$ of this study cases (Table 7).

In a study at Norway, NNM was 0.9 per 1000 in vaginal breech delivery compared with 0.3 per 1000 in vaginal cephalic delivery, and 0.8 per 1000 in those actually born by caesarean delivery (CD) in breech. Compared with planned cephalic delivery, planned vaginal breech delivery was associated with excess risk for NNM (OR 2.4; $95 \%$ CI 1.2 to 4.9 ), while the OR associated with planned breech CD was $1.6(95 \%$ CI 0.7 to 3.7$){ }^{8}$ 
In the present study, mortality in vaginal breech delivery cannot be compared to caesarean group with same baby weight as no LSCS was done for babies $<1000$ gm only 1 LSCS done for babies with birth weight between 1000 $1500 \mathrm{gm}$ considering poor salvageability of $<1500 \mathrm{gm}$ in study neonatal intensive care unit (Table 4).

Preterm birth is associated with a high frequency of breech presentation, which increases with decreasing gestational age. ${ }^{9}$ In a study, neonates with planned vaginal delivery and planned caesarean delivery did not differ in survival (93.0 versus $95.7 \%, p=0.14)$. No association between planned caesarean delivery and improved outcomes for preterm breech singletons born at 26-34 weeks of gestation after preterm labour or preterm pre-labour rupture of membranes was found. ${ }^{10}$

In the present series, $58 \%$ of the babies were preterm i.e. $<37$ weeks period of gestation. Maximum mortality is seen prior to 32 weeks (Table 5). There were 23 perinatal deaths among 40 breech deliveries prior to 32 weeks of gestation (Table 5). A premature breech delivery in addition to other problems posed the possibility of head entrapment due to relatively large size of the head, which comes last after the small body has slipped through an incompletely dilated cervix. Death due to respiratory distress is seen in most of the babies with birth weight $<1500 \mathrm{gm}$ (Table 3 and 6). Also, death due to severe birth asphyxia following head entrapment was seen in most babies with weight less than $2000 \mathrm{gm}$. Death due to meconium aspiration was seen in term breech with 2500 to $3500 \mathrm{gm}$ weight. More preterm babies following vaginal delivery were transferred to neonatal intensive care unit (Table 9). Out of 32 babies 16 required endotracheal intubation. All of the birth injuries observed occurred in case of vaginal breech delivery, thus indicating clearly the fetal morbidity associated with it.

\section{CONCLUSION}

A vaginal breech delivery does not necessarily mean successful outcome. A judicious decision of delivering the breech presentation vaginally depends on many factors like patients age, type of breech, expected fetal weight, progress of labour, adequacy of pelvis, skill of the obstetrician, facilities of operative deliveries. But the perinatal outcome does not depend only on the mode of delivery, it is also affected by the weight of the baby, its maturity, associated congenital anomalies, equipped neonatal intensive care unit and also substantially on the expertise of the obstetrician and the neonatologist. The route of delivery should be discussed with women. There must be balance between neonatal outcomes and the higher risks of maternal morbidity associated with caesarean section performed especially at lower gestational age.
Funding: No funding sources

Conflict of interest: None declared

Ethical approval: The study was approved by the Institutional Ethics Committee

\section{REFERENCES}

1. Hickok DE, Gordon DC, Milberg JA, Williams MA, Daling JR. The frequency of breech presentation by gestational age at birth: a large population-based study. Am J Obstet Gynecol. 1992;166:851-52.

2. Hannah ME, Hannah WJ, Hewson SA, Hodnett ED, Saigal S, Willan AR, et al. Planned caesarean section versus planned vaginal birth for breech presentation at term: a randomised multicentre trial. The Lancet. 2000;356(9239):1375-83.

3. ACOG Committee Opinion No. 340: Mode of term singleton breech delivery. Obstet Gynecol. 2006; 108:235-7.

4. ACOG Committee Opinion No. 745: Mode of Term Singleton Breech Delivery. Obstet Gynecol. 2018;132:e60-e63.

5. Whyte H, Hannah ME, Saigal S, Hannah WJ, Hewson S, Amankwah K. Term Breech Trial Collaborative Group. Outcomes of children at 2 years after planned cesarean birth versus planned vaginal birth for breech presentation at term: the International Randomized Term Breech Trial. Am J Obstet Gynecol. 2004;191:864-71.

6. Hannah ME, Whyte H, Hannah WJ, Hewson S, Amankwah K, Cheng M, et al. Term Breech Trial Collaborative Group. Maternal outcomes at 2 years after planned cesarean section versus planned vaginal birth for breech presentation at term: the international randomized Term Breech Trial. Am J Obstet Gynecol. 2004;191:917-27.

7. Ngwenya S. The incidence and perinatal outcomes of singleton vaginal breech deliveries in a low-resource setting, mpilo central hospital, Bulawayo, Zimbabwe. MOJ Womens Health. 2019;8(1):54-6.

8. Bjellmo S, Andersen GL, Martinussen MP, Romundstad PR, Hjelle S, Moster D, et al. Is vaginal breech delivery associated with higher risk for perinatal death and cerebral palsy compared with vaginal cephalic birth? Registry-based cohort study in Norway. BMJ Open. 2017;7(4):e014979.

9. Lorthe E, Quere M, Sentilhes L, Delorme P, Kayem G. Incidence and risk factors of caesarean section in preterm breech births: A population-based cohort study. European J Obstet Gynecol Reprod Biol. 2017;212:3743.

10. Lorthe E, Sentilhes L, Quere M, Lebeaux C, Winer N, Torchin H, et al. EPIPAGE-2 Obstetric Writing Group, Ancel PY. Planned delivery route of preterm breech singletons, and neonatal and 2-year outcomes: a population-based cohort study. Inter J Obstet Gynaecol. 2019;126(1):73-82.

Cite this article as: Raut D, Tadru S, Patil B, Koranne P. Evaluating the factors influencing perinatal outcome in breech presentation. Int $\mathbf{J}$ Reprod Contracept Obstet Gynecol 2020;9:3308-12. 